\title{
Social responsibility and competitiveness in hotels: The role of customer loyalty
}

\author{
Ahmed Mehrez ${ }^{a^{*}}$

\section{CH R O N I C L E} \\ Article history: \\ Received: October 9, 2019 \\ Received in revised format: No- \\ vember 252019 \\ Accepted: December 31, 2019 \\ Available online: \\ December 31, 2019 \\ Keywords: \\ Social Responsibility (SR) \\ Sustainability \\ Customer Loyalty \\ Competitiveness \\ Hotel industry \\ Qatar
}

${ }^{a}$ Department of Management and Marketing, College of Business and Economics, Qatar University, Oatar

\section{A B S T R A C T}

The concept of Social Responsibility (SR) has been evolved during the last decade and most organisations care about their society and the environment. While incorporating SR programs through organizational strategies would be mostly optional, the benefits of "doing a good business" may enhance competitiveness. Hospitality industry is not far from this where hotel sector can achieve several desirable outcomes adopting SR initiatives. Despite the fact that many services are intangible by their nature and they are evaluated based on perceptions, the willingness created by social initiatives can lead to an advantage through brand image. In return, a "good social reputation" can create and maintain customer loyalty in hotels and hospitality. This paper investigates the role of SR on competitiveness through the mediating role of customer loyalty. A model is developed and examined through hotel industry in Qatar. Statistical results show that all research hypotheses were accepted and customer loyalty could be retained by incorporating SR values affecting competitiveness in hospitality industry in Qatar.

\section{Introduction}

Customers may be attracted towards organisations by perceiving how these organisations core values cope with social behaviours (Hui Tsai et al., 2015). Social Responsibility and Sustainability (SR\&S) can be referred as how organisations would incorporate their social commitments in their core strategies and operations (Pino et. al., 2015). As long as the level of SR\&S affects business and community can be enormous in short- and long-term, it is necessary that the level of the SR awareness is highlighted and recognized in different organisations (Kang et. al., 2010). As such shift recognised, organisations need to create value by incorporating SR\&S into their core strategies and operational practices, ultimately contributing to society. In accordance, an increased awareness has emerged among organisations on the concepts of Social Responsibility and how it affects performance and competitiveness (Font et al., 2016). Zappala (2003) argues that organisations; in different fields, would plan to pertain socially responsible and keep chances of survival in modern environment competition. Tsai et al. (2015) state that organisations who are able to incorporate environmental concerns would be able to advance safety, efficiency, and reduce their expenses. This can be reflected on an enhancement of competitive advantage and thus may influence consumer behaviour and loyalty (Kang \& Lee, 2010; Lee et al., 2013). In other words, organisations can turn social responsibility into a regular routine by listening to consumers (Romani et al., 2013). This is the way many studies focused on studying how to align social responsibility to be in line with business strategies (Kamaei, 2015). On line, this research investigates the impact of Social Responsibility on competitiveness exploring the role of customer loyalty with evidences from the hotel industry in Qatar. Theoretical background on Social responsibility is presented followed by model development and hypotheses testing. 


\section{Theoretical background}

\subsection{Social Responsibility and Sustainability: emergence of a concept}

Social Responsibility and Sustainability (SR\&S) may be considered as a crucial factor in generating and sustaining company status to enhance competitive advantage of these organisations (Park et al., 2014). Menichini and Rosati (2014) argue that this wave is of great importance in such current world concerns as organisations need to reconsider their relationship and consideration with environmental concerns to create a short-term link with consumers and the society and to incorporate themselves as effective members within a society. Walker (2007) argue that the first attempts to conceptualize Social Responsibility can be dated back to the 1960s. In turn, Hui Tsai et al. (2015) defined Social Responsibility as the ethical responsibilities of organisations to enhance its encouraging influences while decreasing its undesirable impact on its community surroundings. In other words, Social Responsibility can be seen as these economical, ethical, legal, and open tasks of an organisation towards the community (Font et al., 2016). Ultimately, social responsibility can be a sense of responding to the community and the capacity of administrating connections between an organisation and community (Herzig \& Moon, 2013). Davis (1973) presented a more comprehensive model on Social Responsibility. Davis explained why and how organizations should act so improving and developing both themselves and the society to which they belong (Davis, 1973). In another more modern trend, Wood (1991) suggested three main outcomes of Social Responsibility in order to trace the concept; namely: Social Policies, Social Programs and Social impact. Carroll (1999) later argued that the social responsibility in any organisation can be divided into four viewpoints: Legal, economical, altruistic and ethical. Wood again (2010) reconsidered these viewpoints are to be associated to not only fiscal disquiets but also to social and communal worries. Needless to shed a light on economical role organisations play to enhance the economy where production of goods and services serves societal needs as a primary target of any organisation. Additionally, organisations need to cope with legal requirements where communities expect that such organisations will always comply with rules and regulations rather than focusing solely on making profit. Moreover, actions that include norms and expectations should be met by organisations while dealing ethically with different stakeholders (Carroll, 1999). furthermore, altruistic requirements are related to these organisations to perform and meet communal hopes such as any good civilian (Akter, 2015).

\subsection{Social Responsibility and Customer loyalty}

Customer loyalty may be perceived through consumers word of mouth reactions, intention to buy, intention to support, and satisfaction (Kang \& Hustvedt, 2013). Consumers are intended to be the most crucial entity of organizational activities (Marin et al., 2009). Baber et al. (2016) argue that "word of mouth" is a concept that designates consumers preference which in turn may shape these customers attitudes turning it into loyalty. Pino et al. (2015) state that if one consumer is to indorse a specific brand, this is to slants other customers minds to that brand while making a decision of buying. On the same manner, Romani et al. (2013) concluded that customers appreciate these organisations that are famous of their socially responsible actions and would share positively such experience. On the same domain, Kang and Hustvedt (2013) confirmed that organisational efforts to be socially responsible would be appreciated by customers touches their behaviours and loyalty towards such organisation. Al-Hawari (2006) added that satisfied consumers create ultimate behavioural outcomes including an intention to repurchase. This is why Loureiro et al. (2012) conclude that Social Responsibility positively affects loyalty of consumers. In accordance, Park et al. (2014) examined a cogent link between consumer attitudes and communal support. Lombart and Louis (2014) also showed that loyalty of consumers lead to satisfaction and affect directly Social Responsibility. In conformity, Marin et al. (2009) explored a substantial confident connection between Social Responsibility and loyalty of consumers.

\subsection{Social Responsibility and Competitiveness}

An organisational obligation to its communal tasks then can have a notable effect on loyalty of customers and thus performance (Sandhu \& Kapoor, 2010). Herzig and Moon (2013) argue that Social Responsibility would lead to a longstanding effect on performance and competitiveness. Many authors highlighted the effect of Social Responsibility on competitiveness and performance (Chen \& Carey, 2009, Kaplan, 2004, Issa, 2011, Omidi \& Shaifee, 2018). Font et al. (2016) confirm that Social Responsibility would increase share of the market which is a corporate measure in advancing competitiveness. Moreover, Vázquez and Hernandez (2014) focused on exploring the role of Social Responsibility can play in enhancing ability to sell which improve competitiveness and performance. By comparing American and Japanese organizations, Kaplan (2004) displayed that sales and profitability are aligned directly to Social Responsibility. Vázquez and Hernandez (2014) Concluded that Social Responsibility has a straight, progressive effect on competitive and performance.

\subsection{Social Responsibility, Customer loyalty and competitiveness, model development}

Social Responsibility then can affect both competitiveness and customer loyalty. Fig. 1 illustrates conceptual model developed after theoretical background. Social Responsibility would directly affect competitiveness and customer loyalty. In addition, customer loyalty may also play a mediating role in affecting competitiveness in organisations. It is already reported that Social Responsibility affects Corporate Social Performance (CSP) and some considered it as an indicator to Social Responsibility outcomes (Hui Tsai et al., 2015). 


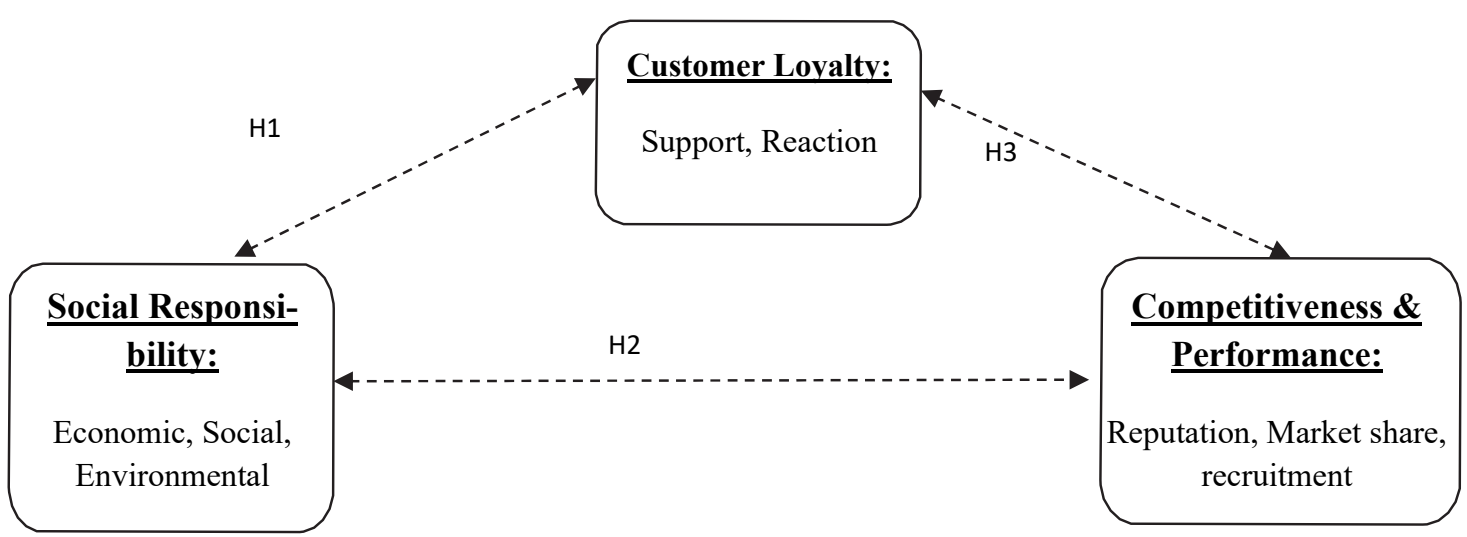

Fig. 1. Conceptual model: Social Responsibility, Customer loyalty and Competitiveness

Lizarzaburu (2012) stated that organisations need to emphasis on recognizing and reacting to their communal needs to improve their social recognition and prestige. Such socially responsible organisations need to build their economic, social and environmental levels to create some positive effects on their communities and thus their own performance (Omidi \& Shafiee, 2018). Wang et al. (2014) indicated that organisations higher competitiveness and performance can be seen as a direct outcome of Social Responsibility actions. In line, Issa (2011) showed that such Social responsible competitiveness can be built through building reputation where organisations need to achieve value of competitive advantage which can be reflected by mental image or superiority. In such manner, organisations would be would be able to enhance their market shares to increase their abilities to recruit and administer a positive situation when it comes to their human resource different activities including training and development, recruiting, compensation and even through their appraisal system (Farooq et al., 2014). This in return will be reflected in a loop of satisfaction in society and may lead to a status of satisfaction among customers leading to sort positive reactions and support in an image of loyalty (Limpanitgul et al., 2013). This is why Chen and Carey (2009) stated that organizational performance can be developed by changing and renovating the social responsibility and through loyal customers. In accordance, a research conceptual model is suggested in Fig. 1 where research hypotheses can be as follows:

$\mathrm{H}_{1}$ : There are mutual effects between Social Responsibility and Customer loyalty.

$\mathrm{H}_{2}$ : There are mutual effects between Social Responsibility and organisational Competitiveness and Performance.

$\mathrm{H}_{3}$ : There are mutual effects between Customer Loyalty and organisational Competitiveness and Performance.

\section{Methodology}

In order to test research hypotheses, a survey questionnaire was developed and distributed to managers and customers in hotels in Qatar. With more than 300 hotels, mostly four and five stars, a sample of 540 respondents participated in this study. A Structure Equation Model (SEM) was used to analyse data using AMOS where Principal Component Analysis (PCA) was completed so minimize the number of measured components and remove influences. In addition, A Confirmatory Factor Analysis (CFA) was adopted for controlling validated element. This also helps in recognizing and settling factors of higher effect. Three main variables are adopted in this research, namely: Social Responsibility, Consumers loyalty, and Competitiveness and Performance (Fig. 2). The first variable; Social Responsibility (SR) can be seen in three levels; Economics (ECO), Environmental (ENV) and Social (SOC) (Vázquez \& Hernandez, 2014). The second variable; Consumer Loyalty (CL) can be seen from two perspectives including Customer reaction (CR) and Support (S) behaviour (Marin et al., 2009; Romani et al., 2013). Competitiveness and performance as a third variable in this study can be divided in three main components including reputation and popularity, recruitment and employment desirability (Tsai et al., 2015) and also though higher market share (Vázquez and Hernandez, 2014).

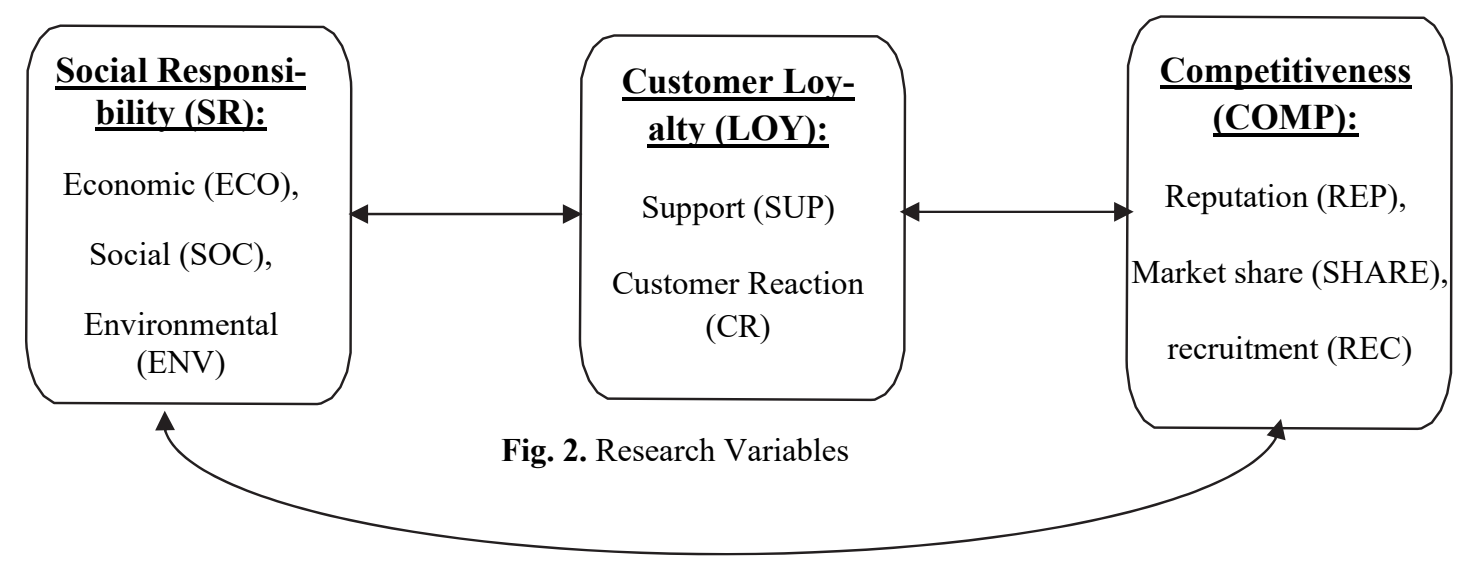




\section{Findings and Results}

Table 1 shows validity and reliability of measured model. In order to confirm model, both Composite Reliability (CR) and Average Variance Extracted (AVE) measured. As seen in Table 1, all research concepts have exceeded 0.50 which indicates that model can be confirmed. In conformance, all $\mathrm{CR}$ values 0.60 . In validating the model, all factors are higher than 0.05 where $\mathrm{p}$ is less than 0.01 . In other words, convergent validity can be assured (Fig. 2).

Table 1

Reliability and validity of research constructs

\begin{tabular}{ccccc}
\hline Hypothesised Path & Estimated coefficient & $\boldsymbol{\lambda}^{2}$ & E & AVE \\
\hline SOC ---- SR & 0.52 & 0.26 & 0.73 & 0.52 \\
ENV ---- SR & 0.50 & 0.25 & 0.72 & 0.63 \\
ECO ---- SR & 0.78 & 0.60 & 0.40 & 0.51 \\
\hline SUP ---- LOY & 0.57 & 0.33 & 0.67 & 0.59 \\
CR --- LOY & 0.79 & 0.62 & 0.38 & 0.78 \\
REP ---- COMP & 0.72 & 0.52 & 0.40 & 0.75 \\
SHARE --- COMP & 0.78 & 0.60 & \\
\hline
\end{tabular}

Following to confirming validity and reliability of model, the measurement model was used for confirming significance. As in Table 2, it can be seen model can provide satisfactory fit of data. Additionally, Fig. 2 shows that all factor loadings including SR, LOY and COMP are more than 0.05 which confirm significance of model. In other word, significance of the model is notable.

Table 2

Fitness Indices-standard measured model

\begin{tabular}{cccccccccc}
\hline CMIN/DF & & & & & & & RMSEA \\
\hline 3.480 & .000 & .048 & .949 & .918 & .548 & .923 & .943 & 0.069 \\
\hline
\end{tabular}

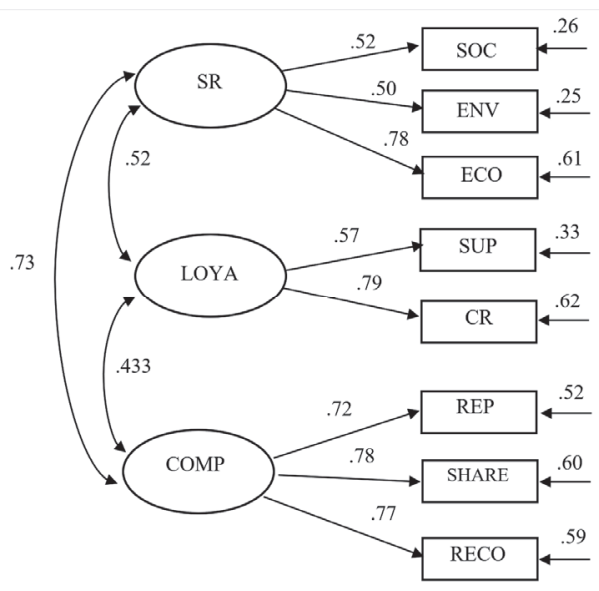

Fig. 2. The standard measurement of research model

As shown in Fig. 2 and as there is no problem in estimation while Standard Estimation Coefficient $(\beta)$ is significant for all routes with bootstrapping at $\mathrm{p}=0.05$, it can be concluded that estimates would be considered fitting. Next, it is time to confirm both reliability and validity of the whole model. In order to do so, both AVE and CR used as shown in Table 3 where both validity and reliability can be confirmed.

Table 3

Reliability and Validity of the structure model

\begin{tabular}{cccc}
\hline Variables & coefficient & AVE & CR \\
\hline SOC & 0.78 & 0.621 & 0.613 \\
ENV & 0.76 & 0.577 & 0.926 \\
ECO & 0.76 & 0.593 & 0.924 \\
SUP & 0.75 & 0.533 & 0.818 \\
CR & 0.72 & 0.499 & 0.818 \\
REP & 0.68 & 0.511 & 0.799 \\
SHARE & 0.75 & 0.488 & 0.754 \\
REC & 0.71 & 0.826 & \\
\hline
\end{tabular}

As long as model is fit, regression is measured examining links among research variables along with Standard Error, Critical Value in order to confirm significance (Table 4). As seen, all relations among research variables look significant. 
Table 4

Regression weights between variables

\begin{tabular}{|c|c|c|c|c|}
\hline Hypothesized Path & Estimated coefficient & $\mathrm{SE}$ & $\mathrm{CV}$ & Significant \\
\hline SOC --- SR & 0.86 & 0.082 & 9.34 & $* * *$ \\
\hline ENV ---- SR & 1.35 & 0.094 & 13.08 & $* * *$ \\
\hline ECO ---- SR & 0.24 & 0.075 & 5.42 & 0.005 \\
\hline SUP ---- LOY & 0.94 & 0.093 & 11.17 & $* * *$ \\
\hline CR ---- LOY & 0.61 & 0.064 & 7.02 & $* * *$ \\
\hline REP ---- COMP & 0.59 & 0.054 & 7.65 & $* * *$ \\
\hline SHARE ---- COMP & 0.17 & 0.079 & 3.96 & 0.009 \\
\hline RECO ---- COMP & 0.99 & 0,068 & 12.68 & $* * *$ \\
\hline
\end{tabular}

\section{Discussion and Conclusion}

It can be concluded that different Social Responsibility extents including Economics, Social and Environmental Responsibilities significantly affect both competitiveness and performance including Popularity, Market Share and also Recruitment and other Human Resource activities in the hotels sector. The model not only focused on this direct link but also extended to explore mutual effects between Customer Loyalty including Customer Reaction and Supportive behaviour and Social Responsibility from one perspective and from Customer Loyalty and competitiveness from the other perspective which were all proven significant. It is notable that these results cope with others in different sectors and/or less formatted models (e.g. Baber et al. (2016), Pino et al. (2015), Tsai et al. (2015), Vasquez et al. (2014), Lombart and Louis (2014), Menichini and Rosati (2014), Vázquez and Hernandez (2014)). So, Customer loyalty can play a mediating role between Social Responsibility and Hotels performance. In other words, competitiveness and performance of an hotel can be achieved when this hotel turns reputable and popular in serving its society leading to loyalty and so higher competing position. Needless to prove that Social Responsibility can act a corner stone in achieving strong image of hotels and hospitality industry in general. While hotels are to adopt Social Responsibility plateau, consumers would be affected indirectly leading to loyalty. Customers would engage a favourable behaviour that supports this hotel directly and even indirectly. Once customers turn devoted to this hotel, they would respond positively affecting all over performance of this hotel. Concluding, Social Responsibility efforts can intensely affect hotels performance. In such manner, hotels may think of getting closer to their societies and customers by enhancing accountability toward this society and hotel guests. In addition, continuous consideration to service quality while observing ecological rules and looking after fiscal conditions of society as well can guarantee a steady, sustainable success of this hotel. Realising that costumers are not only considering services, but also how this service affect their social life would lead to a significant response by hotels incorporating Social Responsibility efforts achieving communal satisfaction and success of their hotels. However, a clear need for more researches can be suggested in this promising field especially in hotels, hospitality and services in general. Though Social Responsibility can be of tremendous importance in competitiveness, it has not received enough consideration in hotels and services in general. It looks critical then that hotels may need to get themselves familiar with notions of Social Responsibility. More in depth researches also may be needed to better understand notion of Customer Loyalty even with the numerous researches in the field, but the possible links between Social Responsibility and Customers loyalty need more attention to explore possible mutual links. More specifically, there is a need to listen more to the society so hotels can incorporate proper Social Responsibility strategic actions in their plans.

\section{References}

Akter, T. (2015). How Women empowerment as a CSR (Corporate Social Responsibility) topic can be taken as competitive advantage to stay competitive in the RMG industry? IOSR Journal of Business and Management, 17(10), 76-81.

Al-Hawari, M. A., \& Ward, T. (2006). The effect of automated service quality on Australian banks' financial performance and the mediating role of customer satisfaction. Marketing Intelligence and Planning, 24(2), 127-147.

Barclay, D., Thompson, R., and Higgins, C. (1995). The Partial Least Squares (PLS) approach to causal modeling: Personal computer adoption and use an illustration. Technology Studies, 2(2), 285-309.

Baber, A., Thurasamy, R., Malik, M. I., Sadiq, B., Islam, S., \& Sajjad, M. (2016). Online word-of-mouth antecedents, attitude and intention-to-purchase electronic products in Pakistan. Telematics and Informatics, 33(2), 388-400.

Carroll, A. (1999). Corporate social responsibility: Evolution of a definitional construct. Business and Society, 38(3), 268295.

Carroll, A. B., \& Shabana, K. M. (2010). The business case for corporate social responsibility: A review of concepts, research and practice. International Journal of Management Reviews, 12(1), 85-105.

Chen, S. X., \& Carey, T. P. (2009). Assessing citizenship behavior in educational contexts: The role of personality, motivation, and culture. Journal of Psychoeducational Assessment, 27(2), 125-137.

Davis, K. (1973). The case for and against business assumption of social responsibilities. The Academy of Management Journal, 16(2), 312- 322 .

Farooq, M., Farooq, O., \& Jasimuddin, S. M. (2014). Employees response to corporate social responsibility: exploring the role of employees' collectivist orientation. European Management Journal, 32(6), 916-927.

Font, X., Guix, M., \& Bonilla-Priego, M. J. (2016). Corporate social responsibility in cruising: Using materiality analysis to create shared value. Tourism Management, 53, 175-186.

Herzig, C., \& Moon, J. (2013). Discourses on corporate social ir/responsibility in the financial sector. Journal of Business Research, 66(10), 1870-1880. 
Tsai, Y. H., Lin, C. P., Ma, H. C., \& Wang, R. T. (2015). Modeling corporate social performance and job pursuit intention: Forecasting the job change of professionals in technology industry. Technological Forecasting and Social Change, 99 , 14-21.

Issa, M. (2011). Preserving corporate reputation in the social media era.

Kang, J., \& Hustvedt, G. (2014). Building trust between consumers and corporations: The role of consumer perceptions of transparency and social responsibility. Journal of Business Ethics, 125(2), 253-265.

Kang, K. H., Lee, S., \& Huh, C. (2010). Impacts of positive and negative corporate social responsibility activities on company performance in the hospitality industry. International journal of hospitality management, 29(1), 72-82.

Kaplan, R. S., \& Norton, D. P. (2004). Strategy Map: Converting Intangible Assets to Tangible Outcomes. Boston: Harvard Business School Press.

Lee, S., Singal, M., \& Kang, K. H. (2013). The corporate social responsibility-financial performance link in the US restaurant industry: do economic conditions matter?. International Journal of Hospitality Management, 32, 2-10.

Limpanitgul, T., Robson, M. J., Gould-Williams, J., \& Lertthaitrakul, W. (2013). Effects of co-worker support and customer cooperation on service employee attitudes and behaviour: Empirical evidence from the airline industry. Journal of Hospitality and Tourism Management, 20, 23-33.

Lizarzaburu, E. R. (2014). Corporate social responsibility and stakeholder strategies: An impact in risk management. Journal of Research in Marketing, 2(1), 98-105.

Lombart, C., \& Louis, D. (2014). A study of the impact of Corporate Social Responsibility and price image on retailer personality and consumers' reactions (satisfaction, trust and loyalty to the retailer). Journal of retailing and consumer services, 21(4), 630-642.

Loureiro, S. M., Sardinha, I. M. D., \& Reijnders, L. (2012). The effect of corporate social responsibility on consumer satisfaction and perceived value: the case of the automobile industry sector in Portugal. Journal of cleaner production, 37 , 172-178.

Marin, L., Ruiz, S., \& Rubio, A. (2009). The role of identity salience in the effects of corporate social responsibility on consumer behavior. Journal of Business Ethics, 84(1), 65-78.

Menichini, T., \& Rosati, F. (2014). The strategic impact of CSR consumer-company alignment. Procedia-Social and Behavioral Sciences, 109, 360-364.

Omidi, F., \& Shafiee, M. M. (2018). The impact of corporate social responsibility on social performance, financial performance and customer reactions in the food industry. International Journal of Business Innovation and Research, 17(2), 249-265.

Park, J., Lee, H., \& Kim, C. (2014). Corporate social responsibilities, consumer trust and corporate reputation: South Korean consumers' perspectives. Journal of Business Research, 67(3), 295-302.

Park, B. I., Chidlow, A., \& Choi, J. (2014). Corporate social responsibility: Stakeholders influence on MNEs' activities. International Business Review, 23(5), 966-980.

Pino, G., Amatulli, C., Angelis, M. D., \& Peluso, A. M. (2015). The influence of corporate social responsibility on consumers' attitudes and intentions toward genetically modified foods: evidence from Italy. Journal of Cleaner Production, 100, 1-9.

Sandhu, H. S., \& Kapoor, S. (2010). Corporate social responsibility initiatives: An analysis of voluntary corporate disclosure. South Asian Journal of Management, 17(2), 47-80.

Vázquez, D. G., \& Hernandez, M. I. (2014). Measuring corporate social responsibility for competitive success at a regional level. Journal of Cleaner Production, 72, 14-22.

Walker, B. M. (2007). Assessing the influence of corporate social responsibility on consumer attitudes in the sport industry. Florida

Wang, W. K., Lu, W. M., Kweh, Q. L., \& Lai, H. W. (2014). Does corporate social responsibility influence the corporate performance of the U.S. telecommunications industry? Telecommunications Policy, 38(7), 580-591.

Wood, D. J. (2010). Measuring corporate social performance: A review. International journal of management reviews, 12(1), 50-84.

Wood, D. (1991). Corporate social performance revisited. Academy of management Review, 16(4), 691-718.

Zappala, G. (2003). Good citizens-strong communities are still good for business. Eureka Street, 13(5), 10-11.

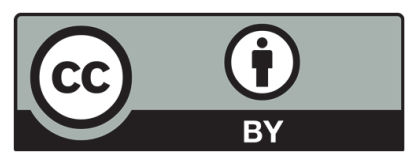

(C) 2020 by the authors; licensee Growing Science, Canada. This is an open access article distributed under the terms and conditions of the Creative Commons Attribution (CC-BY) license (http://creativecommons.org/licenses/by/4.0/). 